How to cite this article:

Adebayo, A. O. (2020). Influence of managerial ability on financial reporting quality evidence from Nigerian listed non-financial firms. Practitioner Research, 2, 25-40.

\title{
INFLUENCE OF MANAGERIAL ABILITY ON FINANCIAL REPORTING QUALITY: EVIDENCE FROM NIGERIAN LISTED NON-FINANCIAL FIRMS
}

\author{
Aderemi Olalere Adebayo, PhD, FCA \\ Department of Accounting \\ Osun State University \\ Osogbo, Osun State, Nigeria
}

Corresponding author:*aderemi.adebayo@uniosun.edu.ng

Received: 06/04/2020 Revised: 07/07/2020 Accepted: 15/08/2020 Published: 06/09/2020

\begin{abstract}
Users of accounting information crave of quality financial reporting, by emphasising on the quality of the auditors neglecting the attribute of the managers. This study investigates the influence of managerial abilities on financial reporting in Nigerian listed non-financial sectors. The time series research design was employed by selecting 40 non-financial institutions as sample size between 2010 and 2017. Secondary data obtained from the financial report were analysed using correlation and logistic regression. It was found that managerial ability has an inverse relationship on financial reporting quality, which is consistent with the agency theory. The finding implied that managers employ their ability to income smoothing for the benefit of the organisation rather than the interest of the shareholders.
\end{abstract}

Keywords: Managerial ability, Financial Reporting Quality, Binary Logistic Regression, Agency Theory, Income Smoothing 


\section{INTRODUCTION}

There is no consensus as to the capability of management and as it affects the quality of financial reports. Naturally, firms with higher management capability are expected to have improved financial reporting quality. However, with prospective shareholders' investment decision to commit their fund in viable organisations, management compensation tied to the performance, coupled with agency problem, researchers, and professionals are of the view that managerial capability may likely promote earnings management but not quality. The management witnessed the low quality of financial reporting practices from several global corporate scandals such as Enron, WorldCom, Global Crossing, and others. There are famous cases of corporate failure from reputable Nigerian listed firms believed to be having highly technical managers, such as lever brothers, Cadbury (Nig) Plc and African Petroleum (Nig) Plc. It is worrisome that till date very few, if any, existed in examining the relationship of managerial capabilities as it affects financial reporting quality despite several corporate failures involving widely known listed firms believed by the public at large to be having necessary human capabilities.

Financial reporting is not a new concept. The concept "Financial reporting" is the joint effort of both the auditor and management of its clients. Traditionally, the management is saddled with the responsibility of furnishing a stewardship report on how the business is managed and controlled on behalf of the owners, arising from contractual obligation as an agent through the financial statement. Also, the management is expected to provide a robust control as an essential integral part of the quality financial report. At the same time, the audit firm examines the financial statement and form an opinion on the financial statement examined by them through the audit report. This research analyses the influence managerial ability has on the quality of financial reporting. We believed that managerial ability had a significant impact on the consistency of financial reporting. More talented managers would prefer to focus more on the normal operating conditions than on the quality of financial reporting. Researchers conclude that the cost of opportunity is a significant factor in the decision-making process of managers and that managers with more time and resources are much more likely to prefer income smoothing (Zang, 2012; Cohen, \& Zarowin, 2010). In a study by Huang and 
Sun (2017), which established the correlation between managerial ability and REM, it was found that higher-capability managers use less activity-based earnings management. They also found that their earnings management is correlated with improved future firm results when such high-capacity managers use accrual-based earnings management.

Firms employ three different levels of management (the strategic, tactical, and operational) with an expected high level of managerial skills. The users of accounting information expect a financial report devoid of material misstatement. At present, investors, professionals, and regulatory bodies not only in Nigeria have raised a concern about the quality of financial reporting. Few studies have examined the issue of managerial capabilities as it affects quality financial reporting. Hence, this study investigated the influence of managerial capabilities on the quality of financial reports on non-financial listed firms in Nigeria.

\section{LITERATURE REVIEW}

\section{Managerial Ability and Financial Reporting Quality}

According to Drucker (1999), "The productivity is not the responsibility of the workers, but the managers", Critical analysis of Drucker's assertion showed that managers should design efficient business processes and make value-adding decisions. The management ability is evident from the use of the input and output produced by the company. Aside from productivity, management plays a vital role in the survival of the company. The management, when fulfilling the survival role, is entrusted with the objective of effectively utilising the resources of the firm to achieve its objective. The objective is mostly affected by the ability of the people in the management team. These capabilities come from education and experience gathered over time. Demerjian et al. (2012) define managerial ability as the ability of a manager to obtain maximum revenue with minimum resources. Managerial capability is measured by the firm's efficiency (obtaining maximum output from minimum inputs). Choi, Han, Jung, and Kang (2015) asserted that managers play a crucial role in the financial reporting process and can influence earnings through their operating decisions. Hambrick (2007) and Kinuu, Murgor, Walter, Letting \& 
Aosa (2012) also report that top executives are essential to firms as their decisions affect the health, wealth, and welfare of their firms.

Bovenzi and Nejezchleb (1985) posit that managerial factors that differentiate firm managers from each other account for the reason why one firm survives and another fails when faced with similar circumstances. These imply that the effect of managers on firm performance is more pronounced than that of the industry as established by Mackey (2008). It, therefore, follows that the performance of managers should be assessed based on the resources in their control by the controllability principle (Atkinson, Banker, Kaplan \& Young, 1997; Horngren, Foster \& Datar, 1997). However, different measures of managerial ability have been established in the literature. Demerjian, Lewis, Lev and McVay, (2012) and Cantrel, (2012) used firms efficiency after controlling for stakeholders variables, Francis, Huang, Rajgopal, and Zang, (2008) employs CEO reputation with the number of articles mentioning the executive supported by (Bertrand \& Schoar, 2003) Managers are responsible for communicating the performance of the company through the financial statements to the stakeholders. The financial report is expected to provide stakeholders with relevant and reliable information for investment decision making. In preparing the financial statements, managers are expected to make decisions such as estimating the future economic value, residual value, and life of long-term assets (Healy \& Wahlen, 1999).

The essential issue of financial reporting quality is that certain accounting information is better and much more credible in comparison with its attribute of conveying what it intends to communicate than other financial reports. Of this reason, reporting consistency is of considerable concern to all types of users interested in the chain of financial reports. The concept of financial accounting quality is, therefore, extensive and covers financial information, disclosures, and non-financial information that is useful for decision-making (Tasios \& Bekiaris, 2012).

The study by Hassan and Bello (2013) claimed that even when operating performance is low, managers significantly increase profits. However, if operating performance is abysmal, several companies might also decrease sales, known as "taking bath" strategies. In particular, the value of financial reporting is measured by its quality (Pounder, 2013). 
In a study by Huang and Sun (2017), it investigated the relationship between managerial ability and real earnings management, and the study found that managers with higher ability would engage in lower real earnings management. Contrary to this, Demerjian et al. (2017) and Hessian (2018) in their study, found that a negative relationship exists between managerial ability and financial reporting quality. Also, Wang et al. (2017) gathered that capable managers would have adequate knowledge of the business operations and could lead to the making of an efficient and effective decision and that managers could influence the quality of financial reporting.

Furthermore, Juliani and Siregar (2019) investigated the effect of managerial ability on the financial reporting quality using listed banks from the Indonesia Stock Exchange during the year 2010 to 2016. The study found that managerial ability maintains a negative effect on financial reporting quality.

\section{Underpinning Theory}

This study premises on agency theory. An association with an agency is a contract in which one or more individuals employ someone else to undertake specific functions on their behest. There is a division of labour between agent and principal, and delegated preference (Rees, 1985). It can also be deduced from the study of Meckling and Jensen (1976), that an agency relationship arises when one or more principal engages another person as their agent. This leads to some decision-making authority being delegated to the agent. This delegation, however, also means the principal must place faith in an agent to behave in the best interests of the principal. A basic model of an organisation implies that due to information asymmetries and self-reliance, principals ignore the reason for trusting their agents and should seek to resolve these issues by placing in effect mechanisms to coordinate agents' desires with principals and reduce the room for information asymmetries and opportunistic actions.

Besides, agents would likely have different vital motivations. They may be influenced by issues that do not correctly apply to the principal, along with financial incentives, labour market conditions, and connections with some other parties. It can lead agents, for example, to a tendency to be more optimistic about the economic consequences 
or success of an individual under a contract than the facts would indicate, it will also be more risk-averse than the principal. Due to such complex desires, agents can be able to manipulate the flow of information. Principals can also raise concerns regarding information asymmetries where agents have knowledge that is not available to principals (Meckling \& Jensen, 1976).

\section{METHODOLOGY}

The study employed a time series research design. To enhances the accuracy of the estimate obtained as a result of the large pool of data available; panel data was employed. Secondary data was obtained from the non-financial companies listed on the Nigerian Stock Exchange during the year 2010 to 2017 . Using purposive sampling techniques, the study selected only 40 out of 113 non-financial firms that have detailed information needed for the current study and firms in which an external auditor has certified its financial reports. To investigate the influence of managerial ability on financial reporting quality, the study conducted correlation and logistic regression. Correlation analysis helps to pinpoint the direction of the relationship between variables. Based on the nature of the measurement of financial reporting quality which is a dichotomous variable, the appropriate tool is Logistic regression analysis.

\section{Model Specification and Measurement of Variables}

Managers are expected to give an account of how resources entrusted are utilised through financial reports to the shareholders. Empirically (Salterio, 2012; Krishnan \& Wang, 2015), managers with high ability can understand accounting systems and procure the right treatment of the transaction. The quality of the financial report of a firm is therefore hinged on the ability of its managers. Their relationship is consistent with agency theory. Mathematically it is stated as thus,

$$
f r=f(M A)
$$

Where. The functional relationship above is stated in the econometric model as $f r q_{i t}=\beta_{0}+\beta_{1} M A_{i t}+e_{i t}$ (2) Financial Reporting Quality is defined as the complement of earnings manipulation. The Financial 
Reporting Quality was estimated using the Beneish Model (1999). Beneish M-score is a mathematical model that uses eight or five financial ratios to identify whether a company has manipulated its earnings. The model is mathematically stated thus:

$$
\begin{aligned}
& \text { M Score }=-4.840+(0.920 \times D S R I)+(0.528 \times G M I)+ \\
& (0.404 \times A Q)+(0.892 \times S G I)+(0.115 \times D E P I)- \\
& (0.172 \times S G A I)+(4.679 \times T A T A)-(0.327 \times L G V I) \\
& \text { M Score }_{5}=-6.0658+(0.823 \times D S R I)+ \\
& (0.906 \times G M I)+(0.593 \times A Q)+(0.717 \times S G I)+ \\
& (0.107 \times D E P I)
\end{aligned}
$$

Where DSRI is Days Sales Receivable Index, GMI is Gross Margin Index, $A Q$ is Audit Quality Index, $S G I$ is Sales Growth Index, DEPI is Depreciation Index, $S G A I$ is Selling, General and Administrative Expense Index, TATA is Total Accruals to Total Assets, and LGVI is Leverage Index. An M-Score higher than -2.22 indicates a substantial likelihood of earnings manipulation while a score less than -2.22 means no manipulations have been made in the accounts. This study used the M Score of five financial ratios.

Control variables that drive financial reporting other than the interest variable (managerial ability) were added to arrive at function (5).

$$
f r q=f(M A, c r l v a r)
$$

Where frq is financial reporting quality, $M A$ is the managerial ability and $\mathrm{crl}$ var represents the control variable. The functional model further stated in econometric form by expanding the control variable shows:

$$
\begin{aligned}
& f r q_{i t}=\beta_{0}+\beta_{1} M A_{i t}+\beta_{2} B I G 4_{i t}+\beta_{3} R O A_{i t}+\beta_{4} L E V_{i t}+ \\
& \beta_{5} S I Z E_{i t}+\beta_{6} A G E_{t}+\beta_{7} Z S C O R E_{i t}+e_{i t}
\end{aligned}
$$

Apriori Expectation

$$
\begin{aligned}
& \beta_{1}, \beta_{2}, \beta_{5} \&, \beta_{6}>0 \\
& \beta_{3,} \beta_{4,}, \&, \beta_{7}<0
\end{aligned}
$$


Where $M A_{i t}$ represents managerial ability, and it is expected to be directly related to financial reporting quality, BIG4 expected to be positively related to financial reporting quality is an indicator variable which indicates one if audited by big four and Zero otherwise. $R O A_{i t}$ represent Return on assets, and it is expected to be inversely related to financial reporting quality $S I Z E_{i t}$ represent the natural log of total assets, which is used to proxy the size of the firm and is expected to have a positive relationship with the financial reporting quality. $L E V_{i t}$ this represents leverage, which is one of the key variables in measuring financial condition, it is expected to be inversely related to financial reporting quality. ZSCORE represents Altman's z-score, which is the key variable in measuring financial condition and it is anticipated to be positively related to financial reporting quality.

\section{Measurement of Variables}

The variables used for the study are measured as follows:

Table 1

Measurement of Variables and Sourc

\begin{tabular}{|c|c|c|c|}
\hline $\mathbf{S} / \mathbf{N}$ & VARIABLES & $\begin{array}{l}\text { DESCRIPTION / } \\
\text { MEASUREMENT }\end{array}$ & SOURCE(S) \\
\hline 1 & $\begin{array}{l}\text { Managerial Ability } M A_{i t}, \\
\text { MANAG_ABILITY }\end{array}$ & Managerial Ability score & $\begin{array}{l}\text { Dermejian et al } \\
\text { (2012) }\end{array}$ \\
\hline 2 & Big Four $\left(B I G 4_{i t}\right)$ & $\begin{array}{l}\text { Dummy variable, one if the } \\
\text { auditor is a Big } 4 \text { and } 0 \text {, } \\
\text { otherwise. }\end{array}$ & Al-Ajmi (2008) \\
\hline 3 & Return on asset $(R O A)$ & $\begin{array}{l}\text { Return on assets (net revenue } \\
\text { divided by total assets) }\end{array}$ & $\begin{array}{l}\text { Eshleman and } \\
\text { Guo (2013) }\end{array}$ \\
\hline 4 & Leverage $\left(L E V_{i t}\right)$ & Total Liabilities to Total Assets & Al-Ajmi (2008) \\
\hline 5 & Size $\left(S I Z E_{i t}\right)$ & Natural log of Total Assets & Al-Ajmi (2008) \\
\hline 6 & Firm Age (Age) & $\begin{array}{l}\text { proxied with the listed age of } \\
\text { the firm in a successive period }\end{array}$ & $\begin{array}{l}\text { Ilaboya et al. } \\
(2017)\end{array}$ \\
\hline 7 & Z-Score & Altman's Z-score & Altman (1968) \\
\hline
\end{tabular}




\section{FINDINGS AND DISCUSSION}

\section{Descriptive Statistics}

Table 2 showed the descriptive statistics of financial reporting quality (FRQ) using the Benish Model of dichotomous variable, managerial ability (MA), the BIG4, Return on Asset (ROA), leverage (LEV ) which measures the capital structure of the firm, SIZE measured by the natural logarithm of total asset, AGE of the firm and while financial condition of the firm(Z_SCORE) for eight years period (2010 - 2017). An illustration of the mean, median, maximum and minimum values, standard deviation, skewness, for the 40 non - financial listed firms in the Nigeria stock exchange is in Table 2.

The mean and (median) of FRQ was 0.622 (1.000) showed that the majority of the listed firms in the non-financial industry engaged in fraudulent financial reporting the statistics showed that $62.22 \%$ of the sampled firms engaged in fraudulent financial reporting. Also, mean and (median) of managerial ability from $-0.000(-0.050)$ indicated that most of the observation has a negative managerial ability while mean and (median) of the BIG4, statistics showed that 0.559 (1.000) that 55.9 percent of the sampled firms were audited by the Big 4 , the median result also validated the statistics showing that all the firms operating in the industry lies within the 50 percentile.

Furthermore, Table 2 statistics on the return on asset showed that the industry is less profitable but highly volatile with a mean score of 0.193 , indicating that the industrial profitability rate of $19.3 \%$ but with a standard deviation of 2.703 showing that the industry has high operating risk. The statistics of the leverage, which represented the capital structure of the firm indicated that the industry is highly geared, with a mean value of 0.889 , indicating that the industry is debt finance to 88.9 percent. 
Practitioner Research Vol. 2, July, 2020, 25-40

Table 2

Descriptive Statistics of Variables

\begin{tabular}{lcccccc}
\hline Variables & Mean & Median & Maximum & Minimum & Std. Dev. & obs \\
\hline FRQ & 0.622 & 1.000 & 1.000 & 0.000 & 0.486 & 320 \\
MA & 0.000 & -0.050 & 0.661 & -0.510 & 0.192 & 279 \\
BIG4 & 0.559 & 1.000 & 1.000 & 0.000 & 0.497 & 320 \\
ROA & 0.193 & 0.106 & 9.278 & -40.484 & 2.703 & 320 \\
LEV & 0.889 & 0.556 & 0.946 & 0.000 & 2.242 & 320 \\
SIZE & 16.386 & 16.606 & 20.763 & 10.626 & 2.035 & 317 \\
AGE & 40.750 & 42.000 & 94.000 & 2.000 & 21.316 & 320 \\
Z_SCORE & 8.395 & 6.614 & 192.425 & -34.157 & 17.804 & 320 \\
\hline
\end{tabular}

Author Computation (2019)

Where FRQ represents financial reporting quality using the Benish Model of dichotomous variables, MA stands for managerial ability, BIG4 connotes Audit Size, ROA proxies Return on Asset, LEV is the leverage which measures the capital structure of the firm, SIZE describes the natural logarithm of total asset, AGE is age and while Z_SCORE measure the financial condition of the firm.

\section{Correlation Matrix}

Table 3 signifies the pairwise Pearson Correlation (Pc) Matrix of all the variables in equation 7 . The result shown in the Table indicated that there was a significant negative correlation between financial reporting quality and managerial capabilities at $(\mathrm{Pc}=-0.03)$ and at a $5 \%$ level of significance. It signified that there is a likelihood of earning management practices by the management. The result also indicated that the Age of the firm and financial condition also have a negative association with the financial reporting quality; this is evidence from the $\mathrm{Pc}=-0.07$ and $\mathrm{Pc}=-0.10$, respectively. The Age of the firm association with financial reporting quality also corroborated that as the firm age increases, management abilities increases, through learning effect, but there is evidence of the low quality of financial reporting.

Table 3 provided information that the larger audit firm has a positive association but not a significant association with financial reporting quality with $\mathrm{Pc}=-0.07$ but a significant value greater than $5 \%$. 
In conclusion, the pairwise correlation of variables in equation 7 using Pearson is lower than the threshold of 0.8 . Hence, there is a high likelihood that the model will not suffer any form of a multicollinearity problem.

Table 3

Correlation Matrix

\begin{tabular}{lllllllll}
\hline VARIABLES & $\mathbf{1}$ & $\mathbf{2}$ & $\mathbf{3}$ & $\mathbf{4}$ & $\mathbf{5}$ & $\mathbf{6}$ & $\mathbf{7}$ & $\mathbf{8}$ \\
\hline FRQ (1) & 1.00 & & & & & & & \\
& 0.00 & & & & & & & \\
M.A (2) & -0.03 & 1.00 & & & & & & \\
& 0.04 & ----- & & & & & & \\
BIG4 (3) & 0.08 & 0.03 & 1.00 & & & & & \\
& 0.20 & 0.61 & ----- & & & & & \\
ROA (4) & -0.01 & -0.06 & 0.00 & 1.00 & & & & \\
& 0.94 & 0.31 & 0.95 & ---- & & & & \\
LEV (5) & -0.02 & 0.07 & -0.07 & -0.03 & 1.00 & & & \\
& 0.75 & 0.25 & 0.24 & 0.57 & ---- & & & \\
SIZE (6) & 0.03 & -0.16 & 0.29 & -0.05 & 0.01 & 1.00 & & \\
& 0.65 & 0.01 & 0.00 & 0.42 & 0.85 & ----- & & \\
AGE (7) & -0.07 & 0.08 & 0.11 & 0.02 & 0.15 & -0.15 & 1.00 & \\
& 0.08 & 0.02 & 0.06 & 0.72 & 0.01 & 0.01 & ----- & \\
Z_SCORE (8) & 0.10 & 0.06 & 0.00 & -0.99 & 0.14 & 0.05 & 0.05 & 1.00 \\
& 0.04 & 0.30 & 0.96 & 0.00 & 0.02 & 0.44 & 0.09 & ---- \\
\hline A & 0.04 &
\end{tabular}

Author Computation (2019)

Where FRQ represents financial reporting quality using the Benish Model of dichotomous variable, MA stands for managerial ability, BIG4 connotes Audit Size, ROA proxies Return on Asset, LEV is the leverage which measures the capital structure of the firm, SIZE describes the natural logarithm of total asset, AGE is age and while Z_SCORE measure financial condition of the firm

\section{Regression Analysis}

A logistic regression model was adopted as a method of estimating Equation 7, and the result presented in Table 4. The dependent variable, financial reporting quality (FRQ) was estimated by Beneish M-Score (1999). According to Beneish (1999), an M-Score higher than -2.22 suggests that the firm is a manipulator while an M-Score 
less than -2.22 suggests the firm is not a manipulator. Consequently, the output was proxied by 1 , if the firm is not a manipulator and 0 if the firm is a manipulator.

The result showed that managerial ability (MA) has a significant negative association with financial reporting quality (coef $=-10.58, \mathrm{z}$ $=-2.22$ ), the result connoted the likelihood of management directing their capabilities toward manipulating earning rather than quality financial reporting. The significant negative relationship of the financial reporting quality and the age of the firm with a statistics of (coef $=--2.24, \mathrm{z}=--2.77$ ) indicated that the low financial reporting quality is firmly related (to achieve a specific firm's objectives) rather than management manipulating for own benefit. The inverse relationship between a firm's age and financial reporting quality could be associated with listing requirements when an infant firm provides quality financial reporting so that it cannot be delisted as of the firm's ages the quality is eroded. The association of the financial condition and financial reporting quality also indicated a negative association with a statistic of (coef $=-12.85, \mathrm{z}=-2.41$ ). The result further validated that low financial reporting quality could be as a result of the poor financial condition of the firm. The result of the study is consistent with the study of (Demerjian et al.,2017; Baik, Choi \& Farber, 2017; Hessian, 2018).

The result of the logistic regression in Table 4 showed that the Nigerian non-financial Listed companies exhibit lower financial reporting quality as a result of the board target for its managerial staff probably due to pressure from the financial condition of the firm.

Table 4

Logistic Regression of Managerial ability and Financial Reporting Quality

\begin{tabular}{lrc}
\hline Var & Coef & Z-stat \\
\hline M.A & -10.58 & $-2.22 * *$ \\
BIG4 & 0.44 & 1.61 \\
ROA & -97.99 & -0.89 \\
\hline
\end{tabular}




\begin{tabular}{lrl}
\hline Var & Coef & z-stat \\
\hline LEV & 123.27 & 0.89 \\
SIZE & -0.02 & -0.28 \\
AGE & -2.24 & $-2.77^{* *}$ \\
Z_SCORE & -12.85 & $-2.41^{* *}$ \\
C & 95.21 & 0.89 \\
\hline
\end{tabular}

Author Computation (2019)

The Table showed the coefficients and $t$-statistics of regression from Equation 7 using Logistic Regression. $* * *, * * \& *$ indicated level of significance at 1\%, 5\% \& $10 \%$ respectively Where FRQ represents financial reporting quality using the Benish Model of dichotomous variable, MA stands for managerial ability, BIG4 connotes Audit Size, ROA proxies Return on Asset, LEV is the leverage which measures the capital structure of the firm, SIZE describes the natural logarithm of total asset, AGE is age and while Z_SCORE measure the financial condition of the firm.

\section{CONCLUSION}

This study investigates the effect of managerial abilities on financial reporting in Nigerian listed non-financial sector, using time series research design, the study selected 40 non-financial institutions as sample size between 2010 and 2017. The study concluded that managerial ability has an inverse relationship to financial reporting quality, which is consistent with the agency theory. It Implies that managers employ their ability to smooth income for the benefit of the organisation but not for the interest of the shareholders.

Therefore, the study recommended that to enhance the quality of financial reports, non-financial sectors shareholders should ensure there is increase efficiency and effectiveness of the board.

\section{ACKNOWLEDGMENT}

This research received no specific grant from any funding agency in the public, commercial, or not-for-profit sectors. 


\section{REFERENCES}

Al-Ajmi, J. (2008). Audit and reporting delays: Evidence from an emerging market. Advances in Accounting, incorporating Advances in International Accounting, 24(2) 217-226.

Altman, E. (1968). Financial ratios, discriminant analysis, and the prediction of corporate bankruptcy. The Journal of Finance, 23(4), 589-609.

Atkinson, A. A., Banker, R. J., Kaplan, R. S., \& Young, S. M. (1997). Management Accounting. New Jersey: Prentice-Hall.

Baik, B., Farber, D., \& Lee, S. (2016). CEO ability and management earnings forecasts. Contemporary Accounting Research, 16451668.

Beneish, M. D. (1999). Incentives and Penalties Related to Earnings Overstatements That Violate GAAP. The Accounting Review,74(4).

Bertrand, M., \& Schoar, A. (2003). Managing with style: the effect of managers on firm policies. The Quarterly Journal of Economics, 118(4), 1169-1208.

Bovenzi, J., \& Najachleb, L. (1985). Bank failures: Why are so many? Issues in Banking Regulations, 8, 54-68.

Cantrell, B. (2012). Bank managerial ability and accounting: Do better managers report higher quality loan loss reserves and fair values?

Choi, W., Han, S., Jung, S., \& Kang, T. (2015). CEO's operating ability and the association between accruals and future cash flows. Journal of Business Finance and Accounting, 42(October 2014), 619-634. doi:http://doi.org/10.1111/jbfa.12118.

Cohen, D. A., \& Zarowin, P. (2010). Accrual-based and real earnings management activities around seasoned equity offerings. Journal of accounting and Economics, 50(1), 2-19.

Demerjian, P., Lev, B., \& McVay, S. (2012). Quantifying Managerial Ability: A New Measure and Validity Tests. Management Science, 58(7), 1229-1248.

Demerjian, P., Lewis, M., \& McVay, S. (2017). How Does Intentional Earnings Smoothing Vary With Managerial Ability? Journal of Accounting Auditing \& Finance, 1-32.

Drucker, P. F. (1999). Knowledge-worker productivity: The biggest challenge. California management review, 41(2), 79-94. 
Francis, J., Huang, A., Rajgopal, S., \& Zang, A. (2008). CEO reputation and earnings quality. Contemporary Accounting Research, 25(1), 109-147.

Hambrick, D. (2007). Upper echelons Theory: An Update. Academy of Management Review, 32(2), 334-343.

Healy, P. M., \& Wahlen, J. (1999). A Review of the Earnings Management Literature and its implication for Standard Setting. Accounting Horizons, 13(4), 365-383.

Hassan, S. U., \& Bello, A. (2013). Firm characteristics and financial reporting quality of listed manufacturing firms in Nigeria. International Journal of Accounting, Banking and Management, 1(6), 47-63.

Huang, X., \& Sun, L. (2017). Managerial ability and Real Earnings Management: advances in accounting. Elsevier, 39(C), 91-104. Ilaboya, O. J., Izevbekhai, M. O., \& Ohiokha, G. (2017). Determinant of Abnormal Audit Fees in Nigerian Quoted Companies. Ekon, Misao Praska, 26, 65-83.

Juliani, S., \& Siregar, S. V. (2019). The Effect of Managerial Ability on Financial Reporting Quality: An Empirical Analysis of the Banking Industry. eAI journal

Kinuu, D., Murgor, P., Walter, O., Letting, N., \& Aosa, E. (2012). Upper Echelons Theory and Research: A review of theory and empirical literature 28 years later. Prime Journal of Business Administration and Management (BAM), 2(10), 697-703.

Krishnan, G. V., \& Wang, C. (2015). The relation between managerial ability and audit fees and going concern opinions. Auditing: A Journal of Practice \& Theory, 34(3), 139-160.

Mackey, A. (2008). The effect of CEOs on firm performance. Strategic Management Journal, 29, 1357-1367.

Meckling, W. H., \& Jensen, M. C. (1976). Theory of the firm: Managerial behavior, agency costs and ownership structure. Journal of financial economics, 3(4), 305-360.

Pounder, B. (2013). Have We Lost Our Ability to Improve Financial Reporting?. Strategic Finance, 95(4), 16

Rees, R., (1985). The theory of principal and agent, Part I. Bulletin of Economic Research 37, 3-26 and 75-95.

Salterio, S. (2012). Balancing the scorecard through academic accounting research: Opportunity lost? Journal of Accounting \& Organizational Change, 8(4), 458-474. 
Tasios, S., \& Bekiaris, M. (2012). Auditor's perceptions of financial reporting quality: the case of Greece. International Journal of Accounting and Financial Reporting, 2(1), 57.

Wang, Z., Chen, M. H., Chin, C. L., \& Zheng, Q. (2017). Managerial ability, political connections, and fraudulent financial reporting in China. Journal of Accounting and Public Policy, 36(2), 141162.Zang, A. Y. (2012). Evidence on the trade-off between real activities manipulation and accrual-based earnings management. The accounting review, 87(2), 675-703. 